Article

\title{
Polite Language Forms as Markers of an Emerging New Language Order in Nikkei-Brazilian Japanese
}

\author{
Akemi Yamashita \\ Former Professor of Meikai Graduate School of Linguistics \& Faculty of Language and Cultures, \\ Meikai University, 1 Akemi, Urayasu-city, Chiba 279-8550, Japan; auroralinda@nifty.com
}

Received: 29 April 2019; Accepted: 19 June 2019; Published: 27 June 2019

\begin{abstract}
This paper presents the results from a linguistically-oriented discourse-completion questionnaire administered in Nikkei-Brazilian (Japanese Brazilian) communities, examining in particular: (1) the use of polite language forms, (2) terms used to address one's spouse, as well as (3) the social characteristics and cultural backgrounds of the informants (e.g., age, sex, generation, nationality, place of birth, place of residence, whether they have lived in the Colonia (i.e., rural communities originally established as exclusively Japanese settlements), where their parents come from, education, and their first language). In this paper, I argue that the use of polite language forms in Nikkei-Brazilian Japanese reflects the different social histories that the two groups identified in this study have been through. The first group consists of those who have experience of Colonia society, whose characteristic use of polite language forms includes: (a) traditional Japanese spousal address terms, such as otoo-san or otoo-chan (father) when the wife addresses her spouse, and okaa-san or okaa-chan (mother) when the husband addresses his spouse; (b) the Western Japanese dialectal polite suffixes -reru/-rareru; and (c) exalting and humbling polite language forms which indicate the relative social positions of the addressees. The second group consists of those who reside in urban areas without experience of life in the Colonia, whose characteristic use of polite language forms includes: (a) Brazilian Portuguese spousal address terms; (b) the use of polite language forms which show the speaker's friendliness and distance-reducing; and (c) a greater use of standard polite language forms, namely -desu, -masu.
\end{abstract}

Keywords: Nikkei-Brazilian; Colonia; urbanization; politeness; polite language forms; address terms; influence of the western Japanese dialect

\section{Introduction}

In the standard Japanese language, polite language forms are ornately structured and highly prescribed so that one cannot communicate without them, whereas in nonstandard dialects of Japanese, they tend to be simpler and have smaller repertories. On the other hand, the typical politeness system of Brazilian Portuguese is oriented towards the widely attested T-V distinction $(t u-v o c \hat{e}$ in Portuguese). Thus, here I ask what sort of polite language forms are used by Brazilian-Japanese who have had access to Japanese nonstandard dialects, standard Japanese, and Brazilian Portuguese in their community history.

Brazil is home to some 1.4 million Japanese immigrants and their descendants. The term "Nikkei" is commonly used to refer to those people in Brazil, but definitions in the literature can vary. In this paper, "Nikkei-Brazilians" refers to the children of Japanese who immigrated to Brazil (i.e., second generation, nisei) and their descendents (i.e., third and fourth generations, sansei and yonsei). However, issei, the first generation, refers only to those who migrated to Brazil before the age of six; hence, adult immigrants are not included as Nikkei-Brazilians in this study, because they have already passed the critical period of language acquisition. 
In this study, two distinct Japanese speech communities were identified on the basis of community history. The first type is called the Colonia-the Japanese settlement villages organized by both the Japanese and Brazilian governments to accommodate Japanese immigrants, and which exist throughout Brazil but are particularly concentrated around São Paulo. In the Colonia, traditional Japanese events, religion, language, and lifestyle are maintained, even today. They are exclusively Japanese communities in which there are extremely dense and multiplex social networks amongst members. ${ }^{1}$ They have their own Buddhist temples and hospitals, where Japanese is used, and gathering places called bunkyoo (e.g., Sociedade Brasileira de Cultura Japonesa e de Assistência Social, Brazilian Society of Japanese Culture and Social Welfare), where members can join numerous club activities (e.g., playing the board game go, or the martial art kendo, learning about bonsai for male members, Japanese flower arrangement, learning/practicing the tea ceremony and traditional dancing for female members, as well as the Japanese poetry form of haiku, and folk and karaoke song contests for all members) and where they receive legal advice in Japanese on complex matters of contemporary life such as insurance. In terms of language education, ample opportunities are provided not only by schools, where Japanese is the language of instruction, but also by the temples and local bunkyoo, where Japanese is taught as an additional language. Importantly, through such organized communal life in the Colonia, members acquire traditional verbal and nonverbal Japanese strategies of showing respect to elders.

The second type of community I will label "urban". Here, the Colonia members left rural agricultural life, moving to urban areas in Brazil, especially after the Second World War, with the aim of assimilating into Brazilian society as Brazilians rather than as Japanese. They are mainly third-generation and were thoroughly educated in Brazilian schools but later went to Japanese language schools to learn their parents' language when they became more aware of their ethnic heritage and when the Japanese economy was booming during the period of 1980s-2000s. Many Nikkei-Brazilians have undergone profound changes in ethnic self-identity and in their livelihood as a result of this urbanization.

A previous study (Yamashita 1995) examined, from a macro-perspective, the extent to which Japanese is used in Brazil, revealing that in the Colonia, half the population used Japanese exclusively, while in urban areas, half the population used Japanese only in the home. In this paper, I focus in more detail on the linguistic characteristics of their Japanese, particularly examining their use of both polite language forms and spousal address terms.

The approach taken in this paper is: (1) to provide the historical and linguistic context of the Japanese community in Brazil; (2) to describe the data collection instrument and methods used in this research; and (3) to familiarize the reader with the data analysis technique employed, before (4) presenting the results and discussing their implications. For the purpose of this paper, I only examined data extracted from my questionnaire (see Yamashita 2007 for further details about the questionnaire-based research).

\section{Background of the Japanese and Nikkei-Brazilians in Brazil}

In this section, I first describe the history of the Nikkei-Brazilians during the periods both before and after the Second World War, particularly paying attention to the demographics of immigrants in each period (for details, see The Consular and Emigration Affairs Department, The Ministry of Foreign Affairs 1971). I shall then briefly discuss Nikkei-Brazilian life in both the Colonia and the urban areas, as well as the generational differences in the degree of assimilation into Brazilian society.

In accordance with agreements between the Japanese and Brazilian governments, from 1908 until 1941 when indentured labor migration began, some 200,000 Japanese immigrated to Brazil. The demographics of these immigrants suggest a diverse but stable population. First, in terms of geographic origins, the majority came from Western Japan (such as Kumamoto, Fukuoka and

1 However, the Colonia nowadays accepts Brazilians who married Japanese in the community. 
Yamaguchi prefectures) and Okinawa (The Consular and Emigration Affairs Department, The Ministry of Foreign Affairs 1971, pp. 52-53, 140-41). Consequently, a number of different dialects such as varieties of western and Ryûkyûan dialects of Japanese were introduced into the Japanese settlement areas. Second, few immigrants arrived as isolated individuals; only $6.1 \%$ entered as single individuals, while the vast majority $93.9 \%$ were part of family groups, since single entry was not allowed in Brazil (Uchiyama 2001, p. 16). In terms of religion, only $15.5 \%$ of the Japanese immigrants were Christians. The majority, $70.6 \%$, were Buddhists and the rest nonbelievers or believers of other religions $(13.9 \%)$ (Mizuki 1978, p. 17). Given that Christianity is the main religion in Brazil, this led somewhat to the cultural isolation of the Japanese population in Brazilian society. Thirdly, those who immigrated were relatively educated, with a $72.9 \%$ literacy rate (Fujii and Smith 1959, p. 11). ${ }^{2}$ Fourth, in terms of occupation, the majority of the immigrants had previously been farmers $(98.8 \%)$ or had engaged in activities ancillary to agriculture in rural areas (Higa 1982, p. 157; Fujii and Smith 1959, p. 13). In Japan, it was common for farmers to organize mutually co-operative systems in order to increase productivity, engendering strong ties in their social networks. Therefore, for immigrants who started to work in coffee plantations, pre-existing co-operative systems were usefully adopted.

Due to the abolition of the agreement on indentured labor between the Japanese and Brazilian governments, during the post-war period, individual immigration took over from the family-based immigration that had been characteristic of the first period of immigration. From 1945 to the mid-1960s, another 50,000 mostly adult Japanese immigrants arrived. These immigrants tended to be from Western Japan, since individual immigrants often joined their relatives who had already migrated to Brazil (The Consular and Emigration Affairs Department, The Ministry of Foreign Affairs 1971, pp. 7-30).

However, beginning in the mid-1980s when the Japanese economy was booming, a large-scale reverse migration occurred. As many as 310,000 Nikkei-Brazilians were working in Japan from 2006 to 2008 (Mita 2011, p. 24). The term dekasegi (which roughly means 'working away from home') became the popular term used to describe Nikkei-Brazilians both in Japan and Brazil. Currently, many dekasegi in Japan are in immersion Japanese-language classes, and I would predict further changes to the Japanese language spoken in Brazil due to the growing influence of Standard Japanese (see Nakamizu 1996, 1997, 1998; Yamashita 1999a, for sociolinguistic work on dekasegi Nikkei-Brazilians in Japan).

Most Japanese immigrants were initially plantation contract laborers in the pre-War period and lived in the Colonia. The rural location of the Colonia meant that residents often experienced difficulties such as a lack of water and electricity, inadequate roads, and unsanitary housing. However, they understood that the cultivation of cash crops would be essential to their socioeconomic advancement and most aimed to become small, independent landowners. For most, the dream was to educate their children and to have a good social standing in their community. By introducing intensive agriculture, they met with some success. In 1923, a self-census showed that $53 \%$ of the Nikkei-Brazilians were independent farmers, and over one third of some 10,000 households owned their own land (Reichl 1995, p. 40). Although the majority of Nikkei would remain in rural areas throughout the pre-War period, some 2000 resided in urban São Paulo, where ethnic restaurants, stores, health care, legal and immigration assistance, banking and loan services could be found.

The Colonia brought together people from different places of origin (and therefore from different dialect areas) who had been employed in agriculture. Agricultural co-ops provided social and economic services, including education for children, Japanese-language newspapers, and meeting halls. Nihon imin 80nen-shi hensan iinkai (Nihon imin 80nen-shi hensan iinkai 1991, Committee for Compiling Eighty-Year History of Japanese Immigration to Brazil, pp. 245, 342, 385) recognizes that the Colonia structure resulted in economic success, both through organizing cooperative associations and through

2 This rate is higher than the average literacy rate in post-war Japan, which was $42 \%$ (Centro de Estudos Nipo-Brasileiros 1988, pp. 13-19). 
mechanisms of internal social control which unified the population. Through the threat of social ostracism, membership in the associations was virtually compulsory.

Immigrants still recognized the authority of the Imperial Japanese government, in effect treating the Colonia as virtual overseas colonies. The Colonia educational system drew heavily from these Imperial sources (Amemiya 1998). By 1938, the Japanese Ministry of Education, propagandizing nationalism and Emperor worship, was giving financial support to 187 Japanese schools with some 10,000 students. Thus, the pre-War era closed with an immigrant and Nikkei population concentrated in isolated communities with strong emotional ties to the homeland, and with strong community-internal expectations of like-minded thought and behavior. Tellingly, most immigrants in the pre-War period had no interest in assimilation; a 1938 survey of 12,000 households showed that $85 \%$ wanted to return to Japan (Amemiya 1998).

It was not until Japan's defeat in 1945 that the Nikkei began to question the orthodoxy of the Colonia system and to think of establishing themselves permanently in Brazil. Even then, this occurred only partially and gradually, and only after a period of strong intergenerational conflict which fundamentally divided the population. The difficult transition is illustrated by the reluctance of many immigrants to acknowledge the surrender of the Japanese armed forces.

Thus, for several years after the end of the War, perhaps as many as 100,000 Japanese immigrants and Nikkei refused to accept the fact of Japan's defeat. According to Amemiya (1998), this was a result of the population needing to confirm an ethnic identity amid conditions of cultural isolation in a hostile environment, of self-interested wishful thinking, and of fraudulent activities by demagogues supported by violent, secret societies which tolerated no dissent and intimidated and assassinated those who thought differently. Eventually, most of the population did, of course, accept the fact of defeat, but for many, that did not mean a rejection of the idealized Japanese ethos, and a large part of the population attempted to maintain the pre-War Colonia ethos.

Amongst the Nikkei population, there was, though, a change in their dream of "returning to Japan" in favor of "becoming good Brazilians". This was reflected in an urbanization of the Nikkei Colonia population. Individual post-War first-generation immigrants also followed this trend and settled in urban areas. Nagata (1990, p. 61) for example, discussed developments in Assai in the state of Paraná, one of the four largest Colonia settlements. The period from 1947 to 1957 saw rapid development, and the early 1960s were considered its heyday, with the introduction of agricultural mechanization and higher standards of living and education. However, between 1957 and 1981, the population of Assai decreased by more than half, as families left agriculture for the comforts of urban life, exemplifying what Nagata calls "the split of Nikkei society".

By the 1990s, a greater ethnic awareness had begun to emerge amongst the sansei-the third generation Nikkei-and consequently, their interest in Japan and Japanese was revived (Reichl 1995, p. 45). Since new Japanese immigrants have continued to arrive in Brazil, the degree to which Nikkei-Brazilians have assimilated into Brazilian society has never been entirely homogeneous. The movements of the dekasegi also render the nature of the community more complex. By 1990, more than one in eight Nikkei had engaged in work in Japan (Nagata 1990, p. 56).

\section{Sociolinguistic Studies on Brazilian Japanese}

There are a limited number of sociolinguistic studies in relation to Nikkei-Brazilians. One sociolinguistic theme that is often foregrounded in work on Japanese is the linguistic expression of politeness, yet the work carried out on this topic among Nikkei-Brazilians has tended to be impressionistic and anecdotal, with Yamashita (2007), however, providing the first statistical analysis of the use of polite language forms. Nomoto $(1969$, p. 73) suggests that rural Nikkei-Brazilian is "impolite" and attributes this to sociological conditions, including growing up "without respect" for others and "without spiritual refinement", ignorant of polite language forms and their use. The economic conditions, he argues, did not leave them time or energy for the "niceties" of politeness, and 
they abandoned many of the polite language forms that are based on unequal social status, behaving linguistically as if everyone was of equal social rank.

In his study on Japanese language change in Brazil, Suzuki (1982, p. 104) also described rural Nikkei-Japanese as "impolite", featuring a heavy incorporation of dialect from Western Japan and with a distinctive grammar and word usage. He noted the influence of Portuguese on accent and core vocabulary, an influence especially prevalent among children. Both he and Kuyama (2000) pointed to many loan words from Portuguese. The influence of language contact was age-related: The younger the generation, the greater the influence from Portuguese. Handa (1980, p. 79) mentioned that Nikkei-Brazilians were becoming poor at conveying special and sensitive emotion in Japanese.

Higa (1974, p. 29), and a number of scholars subsequently, have argued that the standardization of the Japanese language in Hawaii was based on dialects from the Chugoku district of Western Japan. This is also the case in Brazil, where migrants from Western Japan represented the dominant group of settlers.

Yamashita (1999b, p. 11), using data from the dialect section of the questionnaire in the Appendix A of this article, confirmed that Nikkei-Brazilian Japanese has its roots in the Western Japanese dialect, as well as confirming differences in dialect use between rural and urban Nikkei-Brazilians. The home language understandably greatly influenced the language of later generations. Many words adopted from the western district of Japan can be found in their common Japanese dialect, although the younger generations are not aware of this geographical origin.

Unsurprisingly, the language of the population mirrors its social upheavals. During the pre-War years, a diverse range of Japanese dialects could be heard in the community. However, some western dialects, such as Kumamoto, Fukuoka, and Yamaguchi, gradually emerged as the most influential (Yamashita 2003). In line with Mufwene's (1996, pp. 83-134) founder principle, these dialects have the largest number of speakers and were the earliest to arrive ${ }^{3}$ - their emergence as dominant among Nikkei-Brazilians, then, not unexpected.

\section{Defining Linguistic Variables: Types and Levels of Polite Language Forms and Spousal Address Terms}

\subsection{Types of Polite Language Forms}

For the purposes of this study, it is important to understand what is meant by "polite language forms", both culturally and structurally. In standard Japanese, the use of a polite or nonpolite language form is necessary in order to conform to social norms. The three major factors that control polite language usage are as follows: (1) the relative social position of the speakers; (2) in- or out-group membership; and (3) individual characteristics, the most important of which is gender but which also include age, family background, and other social variables (Ono 1999, p. 153; Minami 1974, p. 27)

Polite language forms are determined by the power relationship between the speaker, the listener and the topic person. The social level of the speaker is related to their role and status in the organization to which they belong. These factors are also related to age, gender, history of education, occupation, and so on.

Concerning in- or out-group membership, "in" refers to the speaker's colleagues or family members. The target person who appears in a topic of a conversation is not always a companion in presence. When a speaker is talking, for example, about her own father (in-group) to unfamiliar guests (out-group), she uses the humble form (see below for the details). On the other hand, when the speaker is speaking about a guest (out-group) or a guest's colleague (out-group) with an in- or out-group member, the polite language form is used. When talking directly to an in-group member, a speaker uses a casual speech style. In terms of gender, women tend to use polite language forms more than men. In practice, all of these factors combine and are processed simultaneously. Regarding

3 I am grateful to Kazuko Matsumoto and David Britain for pointing out the relevance of the founder principle here. 
the social rank of speakers, usually socially "lower-ranked" people use polite language forms when speaking to "higher-ranked" people, though the definitions of "higher" and "lower" are complex due to the interaction of the features described above.

Considering linguistic structures, the honorific system which linguistically encodes polite language forms has traditionally been divided into three categories. First, there is a standard polite form, teineigo. The most important means of expressing politeness using teineigo are (1) adding the polite copula -desu to nouns and adjective, or (2) using the polite affirmative inflection-masu, which is affixed to verb-stems derived from the plain (nonpolite) verb. For example, the teineigo form of the verb 'to say', which has the plain form hanasu, becomes hanashi-masu. Also included in the standard polite category are the noun-adjective-prefixes $o$ - and go- ${ }^{4}$ Both prefixes can be used not only in teineigo, but also in sonkeigo and kenjogo, which is explained in detail below.

Second, there is a humble form, applied to oneself, kenjogo, which is realized through the use of either humble verbs or the so-called "productive honorifics". For example, the humble form of the verb 'to say' may be expressed by means of a productive honorific (o-hanashi-suru; that is, o-/go- is prefixed to the stem of the plain verb hanasu further followed by the light verb suru ${ }_{,}^{5}$ or the honorific humble verb, mooshiageru, may be chosen.

Third, there is an exalting form, applied to others, sonkeigo, which is also expressed through the use of either exalting verbs or, again, productive honorifics. For example, 'to say' may be produced as either ohanashi-ni-naru (that is, o-/go- is prefixed to the plain verb stem hanasu, further followed by ni naru), or the exalting verb ossharu may be chosen. However, the English words "exalting" and "humble" used here infer an extreme sense that does not, perhaps, accurately reflect Japanese usage. Tsujimura (1992, p. 446) highlights two concepts which interact across all categories of polite usage: first, addressee-related concerns, which differentiate speech on the basis of the familiarity of the speakers, and second, referent-related concerns, which require changes in speech according to the topic of the conversation. In practice, both addressee- and referent-related concerns operate together. These ideas are treated further in the Materials section, where they are applied to the questionnaire design.

\subsection{Levels of Polite Forms}

I adopted the National Language Institutes' ranking system (National Language Institute 1983, pp. 62-64) for the use of polite language forms. According to the Institute, there are 5 levels of polite language forms, where Level 5 indicates the politest, while Level 1 indicates the least polite. Level 5 concerns the maximally exalting (sonkei-go) and humble (kenjo-go) forms. As explained in Section 4.1, both sonkei-go and kenjo-go have two ways either to show respect to the addressees or to express the speaker's modesty (i.e., the use of either exalting/humble verbs or productive honorifics). At Level 5 , where a speaker expresses maximum respect to the addressee's or speaker's modesty, however, each form is further followed by the polite affirmative inflection masu. For instance, the verb hanasu (meaning 'say') becomes either osshai-masu (i.e., the exalting verb, ossharu 'say' followed by masu) or o-hanashi-ni-nari-masu (i.e., the productive honorifics, o hanashi ni naru followed by masu). However, it should be noted that not all verbs have exalting or humble forms; hence, for some verbs, there may be only one choice to show respect to the addressees or to be maximally humble oneself.

Level 4, the second highest level of politeness, concerns the use of passive forms as honorifics (i.e., re or rare, the conjunctive forms of reru or rareru), which are followed by either the polite copula desu or the polite affirmative inflection -masu. The plain verb $i k-u$ ' $g o$ ', for instance, becomes $i k a-r e-m a s u$. The verb tabe-ru 'eat' becomes tabe-rare-masu. Interestingly, those re and rare forms are used more commonly in Western Japan than in other areas (Inoue 2004, p. 158; Sanada 1993, pp. 62-75). Sanada describes it is

4 There is a tendency for $o$ - to be prefixed to wago (words of Japanese origin), and go- to kango (words of Chinese origin) (Nishida 1995, p. 100).

5 See Nishida (1995) for an explanation about the construction of verb stem plus the light verb suru. 
an ironic phenomenon; -reru/-rareru are not popular in Tokyo and are used rather in regional common languages, even though this form is simply regularly attached to all the verbs. Another example is introduced by the fact that "kora-reru" (exalting form of 'come') is more frequently used than "irassharu" (exalting form of ' $\mathrm{go}^{\prime}$, 'come' and 'to be' in common language) in western dialects. Such an influence of the Western Japanese dialect in Nikkei-Brazilian Japanese is evident.

Level 3, the middle level of polite language form, has two strategies. An example of the first usage is that the word 'forget' is expressed with the polite prefix $o$ - followed by the plain verb wasureru 'forget' and further by the polite copula desu (i.e., o-wasure-desu). An example of the second usage is that the word 'borrow' is expressed as the polite prefix $o$ - followed by the plain verb kas- $u$ further followed by -kudasai, which is the imperative form of kudasaru, the honorific exalting verb kudasai 'give' (i.e., o-kashi-kudasai).

Level 2, the second lowest level of politeness, concerns the simple use of either the polite affirmative inflection -masu affixed to the plain verb or the polite copula -desu affixed to nouns or adjectives. The verb $i k-u$ 'go' becomes $i k i-m a s u$, while the verb taber-u 'eat' becomes tabe-masu.

Level 1 , the least polite form, concerns the use of plain verbs without any polite suffixes or prefixes. When talking about yourself or your own family members to a friend, plain verbs are used. Plain verbs can be used when talking about others' families when you do not have to show respect, but this is rather unusual. At Level 1, the verb taberu 'eat' is used as taberu (dictionary form of the verb 'to eat'). This is in-group conversation, and a speaker uses a casual speech style.

The following are some examples from the questionnaire (Question 2.2); as shown below, each question does not always provide all five levels of politeness, since there are cases where some words simply cannot be used at a certain level of politeness:

You enter a restaurant with the president of your firm. How do you ask him or her what they want to eat?

(1) shachoo nani o meshiagari-masu-ka? (Level 5)

(2) shachoo nani o o-tabe-ni-nari-masu-ka? (Level 5)

(3) shachoo nani o tabe-rare-masu-ka? (Level 4)

(4) shachoo nani o o-tabe-desuka? (Level 3)

(5) shachoo nani o tabe-masu-ka? (Level 2)

(6) shachoo nani o taberu? (Level 1)

(7) If you wouldn't use any of the answers in (1) to (5), then please write how you would say it.

\subsection{Terms of Spousal Address}

Address terms for spouses were included in this study, since they differ between Japanese and Brazilian Portuguese, as we will see. The address terms reflect respect or courteousness within a family. When you address your partner with 'oi(hey)', you may not ask your partner 'oi, hon o totte kudasaimasen-ka?' (Hey, would you mind taking that book?). There is a grammatical opposition of 'você' and 'o (a) senhor (a)' in Brazilian Portuguese, which corresponds to the verb usage of the second and the third person. 'Você' is used among friends or to address an intimate person, and 'o (a) senhor (a)' is used to address a person with higher social status or an older person. This parallels Japanese polite language forms. Nikkei-Brazilians basically speak Portuguese. It is important to analyze how people use address terms in Japanese when language contact between Japanese and Portuguese has occurred. Address terms are not only related to the usage of different levels of polite verb (i.e., polite or rude), but also to democratization and equality among family members.

In my questionnaire, the terms of spousal address were asked about as follows: "What does your wife (or husband) call you? If you are not married, how does your father (or mother) call your mother (or father)?" A number of possibilities were found. The first type involves such address terms as (o)kaasan 'mother' and (o)toosan 'father'. These are the traditional terms when addressing one's spouse in Japan, whereas the use of his or her name or a term of endearment such as "dear" is not common 
in Japan. Therefore, the first type is regarded as the most traditional and polite. The second type is the use of the first name, which is regarded as relatively less polite than the first type. The third type includes the terms Mama and Papa, which signal the modernization of the family after World War II and which were adopted into Japanese from English in both Japan and Brazil. The fourth type is the term bem 'dear' - a loanword from Portuguese meaning 'my dear' or 'my darling'. The fifth type includes Japanese vocative terms such as oi (a rather direct and rude 'hey!' often used by men socially more powerful than their addressees), and nee (a more egalitarian and friendly 'hey!' often used by women). The sixth type involves the terms (o)baa-san, (o)baa-chan (both meaning 'grandmother') and (o)jii-san, (o)jii-chan (both meaning 'grandfather'). Since these forms of address are used when people criticize their spouses, such as pointing out their shortcomings, they are regarded as very impolite address terms. The seventh type refers to the use of Portuguese address terms, such as mamai, mãe (both meaning 'mother'), and papai, pai (both meaning 'father'). Although the third-generation are not accustomed to speaking in Japanese to their families, the use of these Portuguese words, nevertheless, reflects the way their parents address each other in Japanese-(o)kaasan 'mother' and (o)toosan 'father'.

\section{Methodology}

\subsection{Questionnaire Design: Overview and Discourse Completion Task}

The data obtained for analysis were collected by means of a questionnaire. It may at this point be advisable to address any reservations about the appropriateness of a discourse completion task for this research. Ethnographers may argue that the only valid speech data are those from direct observation, and what respondents say they would do in various situations is not necessarily what they do. The logic is unassailable, and indeed the appropriateness and validity of discourse completion tests (DCT) have provoked long-standing discussions in sociolinguistics. Varghese and BillMyers (1996, p. 39) discuss these concerns, but also note, citing numerous sources, that the method provides a large amount of data on a wide range of difficult-to-observe speech behaviors in a short period of time. Further, data derived from DCT have often been found to be consistent with naturally occurring data, and they have been used in a good number of speech act studies, including the ambitious Cross Cultural Speech Act Realization Project (Müller 2005, p. 20), which investigated requests and apologies across thirteen languages.

In my questionnaire, Part I concerns the level of polite language forms explained in Section 4.2, while Part II is related to the terms of address mentioned in Section 4.3. An English translation of the questionnaire along with the response data is given in Appendix A. ${ }^{6}$ Both describe a situation and ask which, of a number of responses, most closely resembles their likeliest use.

I used Question 2.2 and its multiple choices as examples of discourse completion tasks in Part I (see Section 4.2). For the question "You enter a restaurant with the president of your firm. How do you ask him what he would like to eat?", the choice for the least polite form, Level 1, is Shachoo, nani o taberu?, chosen by 4.3\%; Level 2 is Shachoo, nani o tabemasuka?, chosen by $30.8 \%$; Level 3 for this verb does not exist; Level 4 is Shachoo, nani o taberaremasuka?, chosen by $10.4 \%$; Level 5 has two styles, that is, Shachoo, nani o otabeni narimasuka?, chosen by $13.0 \%$, as well as Shachoo, nani o meshiagarimasuka?, chosen by $38.0 \%$; Other represented $3.5 \%$.

Part II contains two questions concerning spousal address terms. Question 2.14.1 is "(If you are a husband) How do you address your spouse? (If you are single) How does your father address your mother?" As explained in Section 4.3, the choices and results are: 1 . By name, 30.3\%; 2. okaa-san or okaa-chan (mother), $16.2 \%$; 3. obaa-san or obaa-chan (grandmother), $0.4 \% ; 4$. Mama, $4.8 \%$; 5 . mamai or mae, $14.5 \%$; 6. Bem, (dear) 7\%; 7.nee, chotto (hey), $0.9 \%$; 8 . oi (hey), 9.2\%; 9 . Other, $16.2 \%$.

6 However, since responses for polite language tend to lose meaningfulness in translation, and also due to space limitations, only the percentage of each choice (Level 1 to Level 5) is shown without actual examples of multiple choices. 
Question 2.14.2 is "(If you are a wife) How do you address your spouse? (If you are single) How does your mother address your father?". The choices and results are: 1 . By name, 22.3\%; 2. (o)toosan or (o)toochan (father), $21.5 \%$; 3. (o)jiisan or (o)jiichan (grandfather), $0.4 \%$; 4. Papa, 7.1\%; 5. papai or pai, $20.0 \%$; 6. bem (dear), $12.0 \%$; 7. nee, chotto (hey), $2.3 \%$; 8 . Other, $14.4 \%$.

\subsection{Data Collection}

Two different sets of data were collected in this study. The first dataset was collected from Nikkei-Brazilians. The questionnaire was administered to a total of 243 Nikkei-Brazilians with a male/female ratio of $57.4 \% / 42.6 \%$. The sample spanned the four generations currently present in Brazilian society in proportions that reflect the generational balance of the Japanese Brazilian population (Centro de Estudos Nipo-Brasileiros 1988, pp. 13-19). After the Nikkei-Brazilians completed the written questionnaire, I interviewed each person to gain more insight into their language in use. The interview was also useful to gain trust, as most of the informants were people that I was meeting for the first time. The second dataset was collected from the western dialect-speaking region of Japan, namely Kumamoto, Fukuoka, and Yamaguchi, the areas from which the largest numbers of Japanese migrated to Brazil. The same questionnaire that the Nikkei-Brazilians received was distributed to 121 speakers in those areas between the ages of 18 and 70 .

\subsection{Use of Correspondence Analysis}

The responses on the use of the polite prefixes 0 - and $g o-$, the levels of polite language forms (Level 1 to Level 5), polite dialectal forms, and spousal address terms were analyzed using a multivariate analysis tool, related to principal components analysis. ${ }^{7}$ In this case, this enables the researcher to locate 'clusters' of similarly behaving speakers and to then explore what factors those speakers have in common. One advantage of this technique is that it does not require hypotheses for which one is seeking to confirm statistical significance but is a bottom-up approach that identifies groups which can then be explored. Thus, Axes 1 and 2 in Figure 1 below are not dimensions identified by the analyst in advance but highlighted as salient by the correspondence analysis on the basis of the input data and can be interpreted once the clusters on the graph are inspected and explored.

\section{Results and Discussion}

Figure 1 shows an overview of the changes in the Japanese language of Nikkei Brazilian society. The arrow drawn with a large curve in the figure indicates the direction of the big stream of change in Nikkei-Brazilian Japanese.

Importantly, four groups were identifiable in different positions on the plot. $^{8} \mathrm{WJ}$ (Western Japanese), in the lower right, is the immigrant's settlement point. As the majority of the first generation come from Western Japan, many western dialects ( $\diamond$ indicate dialects use) are used in their Japanese. The group located in the lower right quadrant are native Japanese speakers from the western dialect-speaking area of Japan. Address terms include $o \mathrm{i}(\mathbf{\nabla} \mathbf{\Delta}$ indicate addressing), which can be said to be a rude expression from a husband to his wife. Many dialect forms were found in this area (see Yamashita 2007), along with some polite expressions.

Second, the lower left is RNJ (rural Nikkei Japanese), which is spoken by mainly the second generation, living in a Nikkei society and using Level 5 and Level 4. The lower left group contains responses by second generation Nikkei-Brazilians who reside or had resided in the Colonia. ${ }^{9}$ Their

7 More precisely, it is called the Hayashi Quantification Method Type III, employing an online software program made available by Aoki (2005). For more details of correspondence analysis, see Greenacre (1993); Gifi (Gifi 1998).

8 A series of statistical tests confirmed the significance of the distinctiveness of these groups (see Yamashita 2007).

9 The lower right is WJ (Western Japanese), spoken by the first generation. The lower left group is labeled RNJ (rural Nikkei Japanese). The other groups are UNJ (urban Nikkei Japanese) in the upper left quadrant. The upper right quadrant indicates Nikkei Japanese of fourth- and fifth-generation. 
specific linguistic characteristics include the use of spousal address terms, (o)too-san/(o)kaa-san 'father'/'mother' and papa and mama-both traditional and modern Japanese terms of address adopted from English to Japanese both in Japan and Brazil after World War II. In terms of politeness levels ( $\bigcirc$ verb; number indicates degree of politeness), they claimed to use levels as high as 5 and 4, including dialectal Western Japanese politeness forms -reru and -rareru, though their level of politeness as a whole spans the full range from 5 to 1.

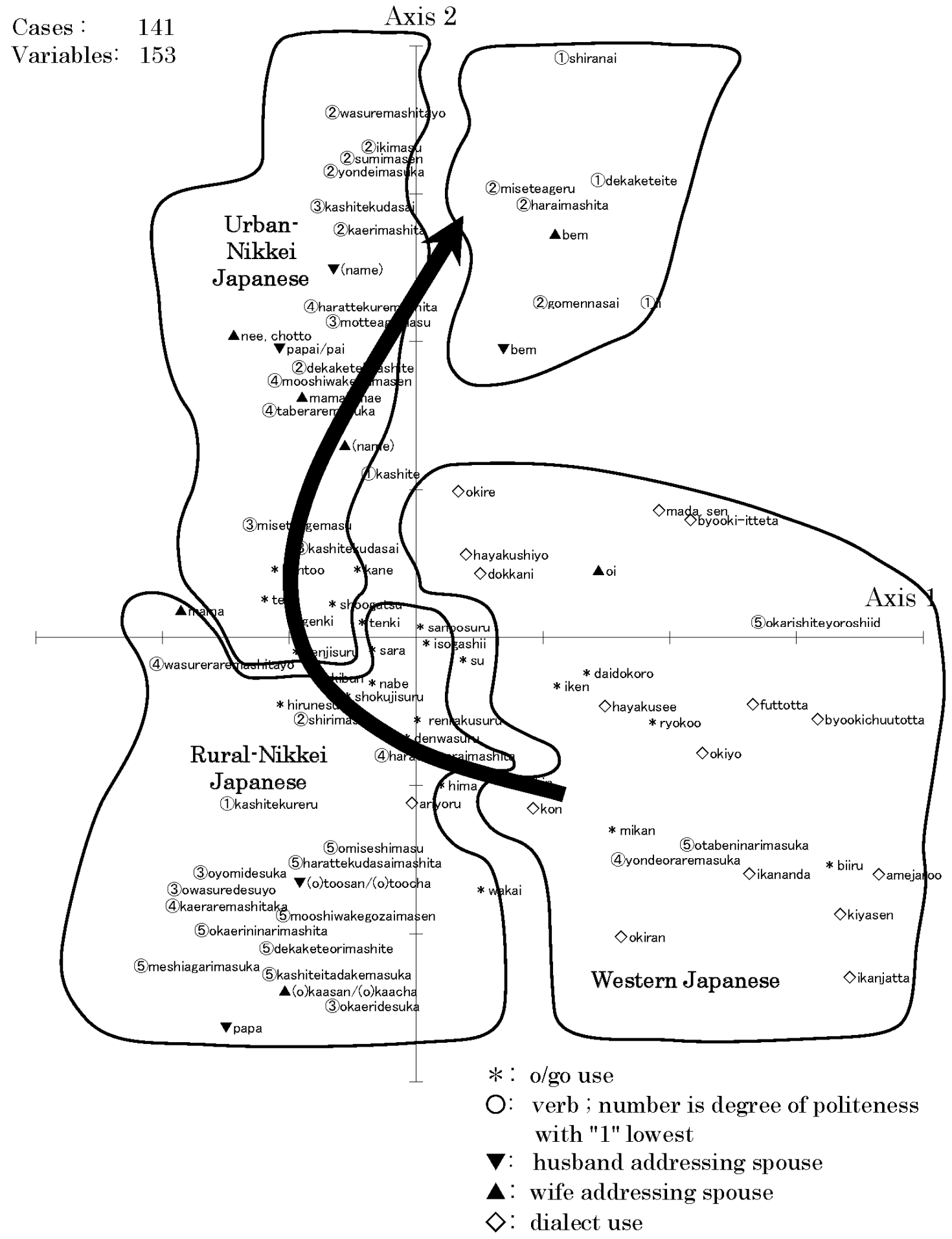

Figure 1. Figure of New Japanese language order in Nikkei-Brazilian communities. 
The third group, UNJ (urban Nikkei Japanese), can be found in the upper left quadrant-responses by third-generation Nikkei-Brazilians residing in urban areas. Their common terms of address to their spouses included: (a) by name, which is common in Portuguese, but which would be odd in Japanese; (b) mamai, mãe/papai, pai, Portuguese words meaning 'mommy'/'daddy' which are usually used by children when addressing their father and mother in Brazil but which would be odd between spouses. As the third generation is not accustomed to speaking in Japanese to their families, they have used these words from Portuguese in order to reflect the ways their parents addressed each other as in (o)kaasan 'mother' and (o)toosan 'father'. Regarding the level of politeness, their use was restricted to Levels 2 and 1, where -desu and -masu forms are mainly used. They do not use exalting nor humbling forms but the polite language forms -desu, -masu and the final particle -ne. Using the final particle -ne compensates somewhat for the lack of exalting/humbling verb use, even though -ne is not polite enough to express consideration to others. The greater use of standard polite -desu,-masu forms is based on the relative distance between the speaker and the listener, rather than hierarchical relationships.

The fourth group in the upper right quadrant indicates the language use of fourth- and fifth-generation Nikkei-Japanese. Language use among this group differs dramatically from the urban and rural Colonia Nikkei-Japanese. Commonly used expressions such as gomenasai 'I am sorry' (Level 2), shiranai 'I don't know' (Level 1), and bem 'my dear' as a term of address can be found.

I now turn to recap the characteristics of both rural Nikkei-Japanese and urban Nikkei- Japanese (see Table 1). The honorific passive forms -reru and -rareru, preferred by the Colonia Nikkei-Brazilians, are forms of respect used for addressees, and especially elders; hence, it can be said that the users still maintain traditional Japanese language order. On the other hand, the use of combinations of -desu or -masu with the final particle -ne by urban Nikkei-Japanese can be interpreted as a preference for distance-reducing expressions or emphasizing closeness, common in Brazilian society. The results reiterate, then, that those who live in exclusively Japanese communities maintain more traditional Japanese politeness forms (including Western Japanese dialectal forms) and terms of address, while those who left the Colonia seeking a more liberal urban lifestyle show some influence from Portuguese in the use of papai, pai 'father' and mamae, mãe 'mother', while displaying limited linguistic repertoires in politeness forms.

Table 1. Comparison of correlation categories across rural and urban Nikkei Japanese.

\begin{tabular}{ccc}
\hline & Rural Nikkei-Japanese & Urban Nikkei-Japanese \\
\hline Generation & Nisei (second generation) & Sansei (third generation) \\
\hline Colonia experience & yes & no \\
\hline Mother tongue & Japanese (rural Nikkei Japanese) & Portuguese \\
\hline Spousal address & otoo-san/-chan, okaa-san/-chan, \\
mama/papa & By name, papai, pai/mamai, mãe \\
\hline Polite language forms & $\begin{array}{c}\text { Frequent use of -reru/-rareru; } \\
\text { various other expressions, but } \\
\text { fewer than in Western Japanese. }\end{array}$ & $\begin{array}{c}\text { Mainly -desu/-masu; frequent use } \\
\text { of -ne (final particle); sometimes } \\
\text {-reru/-rareru. }\end{array}$ \\
\hline
\end{tabular}

There seem to be four factors contributing to the emergence of two different varieties among Nikkei-Brazilians. The first factor is the availability of Japanese language education. Teaching in schools exclusively through the medium of Japanese was banned in 1938, as were Japanese-language media. From 1972 to 1995, however, there was a large increase in the number of nisei and sansei learning Japanese, due both to new educational policies, which lifted the ban on Japanese language education, and the influx of investment from Japanese companies. Although standard Japanese was taught in schools both in the rural Colonia and urban areas, students could also "acquire" Japanese through socializing in the community where the older generations still use western dialects of Japanese. It therefore makes sense that the variety of Japanese used by the second generation in rural areas shows 
some influence from the western dialect; by contrast, in urban areas, the mother tongue for the third generation has become Portuguese- the dominant ambient language. These urbanites learn Japanese either through their parents or Japanese classes, but not through community or social life. Hence, the variety of Japanese used by the third generation in urban areas shows the incorporation of Portuguese as well as standard final particle -ne, but little influence from Western Japanese dialects. ${ }^{10}$

The second factor is the effect of contact with Portuguese. ${ }^{11}$ Firstly, the use of Portuguese forms of spousal address provides evidence of the incorporation of Portuguese words into urban Nikkei-Japanese, likely hastened by the adoption of Portuguese as a mother tongue. Second, given that the final particle -ne compensates somewhat for the lack of exalting/humbling verb use, it can be speculated that distance-reducing expressions, common in Brazilian society, are preferred rather than respectful and courteous/polite expressions. That is, there was a shift from showing deference to demonstrating solidarity. Thus, this has strong influence on the formation of their variety of Japanese.

The third factor is related to the process of social levelling in an isolated pioneer or rapidly changing society. ${ }^{12}$ In this light, the pressure to conform to Japanese social norms was weaker, particularly in urban areas, and consequently, Portuguese words and Brazilian politeness strategies (i.e., using -ne to show friendliness and distance reducing) were more readily incorporated than traditional Japanese politeness strategies (i.e., using respectful and courteous/polite expressions).

Finally, the effects of socioeconomic shifts from a rural to an urban environment are another possible cause for the changes described above, since through this relocation, nisei and sansei typically gained social status, engaged in the operation of small businesses, thus requiring extensive contact with the public, joined Japanese international companies, and worked abroad.

Historical sociolinguists would hope to be able to trace the language development of urban Nikkei-Japanese chronologically, for example, from the Western Japanese dialect, to rural Nikkei and then to urban Nikkei. To do so reliably would, however, require a comparative analysis of language studies regarding Western Japan 100 years ago, the Japanese living in the Colonia more than 50 years ago, and modern urban Nikkei. Regretfully, such historical studies are beyond the scope of this present study. However, further comparisons of rural Nikkei-Japanese and urban Nikkei show many differences, adding weight to the idea that a new language order is emerging.

\section{Conclusions}

An analysis of polite language forms has demonstrated systematic language change in progress among urban Nikkei-Japanese. Furthermore, differences between rural Nikkei and urban Nikkei are present both in the grammatical encoding of politeness and in the choice of spousal address terms. In this new Japanese community, the polite language forms - -desu and -masu are frequently used, as well as Portuguese spousal address terms and names used for addressing spouses.

This study has shown that the language use of rural Nikkei-Japanese and urban Nikkei-Japanese is connected with generation, the Colonia life, and mother tongue. My analysis has also indicated that although "polite" language use by urban Nikkei-Japanese might not be sufficient for the Japanese standards in Japan, they are acceptable to the Nikkei-Brazilian community and therefore considered polite within that community. ${ }^{13}$ The research presented here shows that urban Nikkei-Japanese place more importance on expressing friendliness, and distance-reducing by frequently using the final particle -ne. Nikkei-Brazilian society provides an exceptionally fertile ground for sociolinguistics, and much work remains to be done.

Funding: This research was supported by the Grants-in-Aid for Scientific Research (C) grant number 09680301.

\footnotetext{
See Yamashita (1997) pp. 233-36, Yamashita (2007) pp. 114, 139-42. for details.

See Yamashita (2007) pp. 143, 147-50 for details.

See Yamashita (2007) pp. 113,165-66 for details.

See Yamashita (1997) p. 223 for details.
} 
Acknowledgments: I wish to express my gratitude to the informants. This article has benefited greatly from numerous comments from anonymous reviewers for a number of earlier versions of this article. This paper was written based on Yamashita (2003), presented at the IVth International Congress of Dialectologists and Geolinguists, University of Latvia, Riga and Yamashita (2007). Some part was revised according to the insights and comments by the commentator. I owe a large debt of gratitude to Fumio Inoue, Kazuko Matsumoto and David Britain for their opinions about the methods of this study.

Conflicts of Interest: The author declares no conflict of interest.

\section{Appendix A. Questionnaire with Response Data by 243 Respondents}

Part I. Levels of polite forms

\begin{tabular}{|c|c|c|c|c|c|c|c|}
\hline Questions & I & II & III & VI & $\mathbf{V}$ & Others & Total \\
\hline $\begin{array}{l}\text { 2.1. The teacher is reading a magazine; how would you say, } \\
\text { "What magazine are your reading?" in Japanese? }\end{array}$ & 5.9 & 42.5 & 18.4 & 6.8 & 21.4 & 5.0 & $100 \%$ \\
\hline $\begin{array}{l}\text { 2.2. You enter a restaurant with the president of your firm. } \\
\text { How do you ask him what he would like to eat? }\end{array}$ & 4.3 & 30.8 & 10.4 & 38.0 & 13.0 & 3.5 & $100 \%$ \\
\hline $\begin{array}{l}\text { 2.3. An elderly stranger dropped her handkerchief. What do } \\
\text { you say to her? }\end{array}$ & 9.4 & 43.8 & 8.0 & 35.9 & & 2.9 & $100 \%$ \\
\hline $\begin{array}{l}\text { 2.4. An elderly stranger forgot her umbrella. What do you } \\
\text { say to her? }\end{array}$ & 4.5 & 39.8 & 22.7 & 15.2 & 17.8 & 0 & $100 \%$ \\
\hline $\begin{array}{l}\text { 2.5. At a restaurant after dinner, you found that you did not } \\
\text { have enough money to pay. Your president noticed your } \\
\text { difficulty and paid for you. How would you later tell this to } \\
\text { a friend? }\end{array}$ & 3.2 & 13.8 & 8.5 & 36.7 & 34.8 & 3.0 & $100 \%$ \\
\hline $\begin{array}{l}\text { 2.6.1. There is a doctor with whom you are well acquainted } \\
\text { next to you. How would you ask to borrow a pen? }\end{array}$ & 3.0 & 1.4 & 4.3 & 45.7 & 45.2 & 0.4 & $100 \%$ \\
\hline $\begin{array}{l}\text { 2.6.2. How would you ask to borrow a pen from a close } \\
\text { friend? }\end{array}$ & 9.0 & 30.0 & 22.8 & 33.2 & 2.9 & 2.1 & $100 \%$ \\
\hline $\begin{array}{l}\text { 2.7. A young stranger asks you for directions in town, but } \\
\text { you do not know. How would you answer him? }\end{array}$ & 24.7 & 65.0 & 6.0 & & & 4.3 & $100 \%$ \\
\hline $\begin{array}{l}\text { 2.8. You are invited to a party hosted by your president. } \\
\text { How would you reply? }\end{array}$ & 0.9 & 50.0 & 32.3 & & & 16.8 & $100 \%$ \\
\hline $\begin{array}{l}\text { 2.9. Yesterday, your teacher called you on the telephone, but } \\
\text { you were out. When returning the call, how would you } \\
\text { express regret that you had been out? }\end{array}$ & 10.7 & 43.9 & 42.8 & & & 2.6 & $100 \%$ \\
\hline $\begin{array}{l}\text { 2.10. The teacher's bag seems to be heavy. How would you } \\
\text { offer to help? }\end{array}$ & 2.2 & 1.3 & 7.2 & 11.0 & 73.9 & 4.4 & $100 \%$ \\
\hline $\begin{array}{l}\text { 2.11. You would like to show a picture of your family to } \\
\text { your teacher. How would you express this? }\end{array}$ & 6.2 & 8.0 & 12.0 & 33.3 & 39.2 & 1.3 & $100 \%$ \\
\hline $\begin{array}{l}\text { 2.12. After the president of your firm left the office, there is a } \\
\text { telephone call for him. How would tell the caller that he has } \\
\text { left? }\end{array}$ & 4.4 & 41.4 & 13.2 & 38.8 & & 2.2 & $100 \%$ \\
\hline $\begin{array}{l}\text { 2.13. You are late for an important company meeting. How } \\
\text { would you apologize? }\end{array}$ & 0.9 & 3.5 & 15.2 & 31.3 & 47.4 & 1.7 & $100 \%$ \\
\hline
\end{tabular}

NB: Roman numerals indicate the level of politeness, with I being the least polite and V being the politest, while Arabic numbers indicate the percentage of responses. Note that not all the questions can provide choices at all of the five levels of politeness.

Part II. Terms of address for spouses

2.14.1. (If you are a wife or husband) How do you address your spouse? (If you are single) How does your mother (or father) address your father (or mother)? 


\begin{tabular}{|c|c|c|c|}
\hline Level & Choice & If You Are a Husband & If You Are a Wife \\
\hline $\mathrm{V}$ & $\begin{array}{l}\text { By Japanese words } \\
\text { okaa-san or okaa-chan 'mother' } \\
\text { otoo-san or otoo-chan 'father' }\end{array}$ & 16.2 & 21.5 \\
\hline IV & By name & 30.3 & 22.3 \\
\hline III & $\begin{array}{l}\text { By modern way in Japanese words } \\
\text { (i.e., mama and papa) }\end{array}$ & 4.8 & 7.1 \\
\hline II & By Portuguese & & \\
\hline & (a) mamai or mãe; papai or pai & 14.5 & 20.0 \\
\hline II & (b) bem 'dear' & 7.5 & 12.0 \\
\hline I & nee, chotto 'hey!' & 0.9 & 2.3 \\
\hline I & $\begin{array}{l}\text { (a) oi ‘hey' (rude) } \\
\text { (b) obaa-san or obaa-chan } \\
\text { 'grandmother' }\end{array}$ & $\begin{array}{l}9.2 \\
0.4\end{array}$ & $\begin{array}{c}0 \\
0.4\end{array}$ \\
\hline Other & & 16.2 & 14.4 \\
\hline Total & & $100 \%$ & $100 \%$ \\
\hline
\end{tabular}

Note: number indicates the percentage.

\section{References}

Amemiya, Kozy K. 1998. Being “Japanese” in Brazil and Okinawa. Occasional Paper 13; JPRI (Japan Policy Research Institute, University of San Francisco). Available online: http://www.jpri.org/publications/occasionalpapers/ op13.html (accessed on 9 February 2012).

Aoki, Shigenobu. 2005. Script by AWK Language. Available online: http://aoki2.si.gunma-u.ac.jp/index.html. (accessed on 15 December 1999).

Centro de Estudos Nipo-Brasileiros. 1988. Brajiru ni okeru Nikkei jinkô chôsa Hôkokusho, 1987-1988 [Report of survey on the Population of Japanese Descent, 1987-1988]. São Paulo: Centro de Estudos Nipo-Brasileiros, pp. 13-19.

Fujii, Yukio, and Thomas Lynn Smith. 1959. The Acculturation of the Japanese Immgrants in Brazil. In Latin American Monographs. Gainesville: University of Florida Press, vol. 8.

Gifi, Albert. 1998. Nonlinear Multivariate Analysis. Chichester, New York, Brisbane, Toronto and Singapore: John Wiley and Sons. First published in 1990.

Greenacre, Michael J. 1993. Biplots in Correspondence Analysis. Journal of Applied Statistics 20: 251-69. [CrossRef]

Handa, Tomoo. 1980. Burajiru Nikkei Shakai ni okeru Nihongo no Mondai 1 [Problem of Japanese language in Japanese Brazilian society 1]. Gengo Seikatsu [Language Life] 346: 75-81.

Higa, Masanori. 1974. Hawai no Nihongo no Shakaigengogakuteki kenkyû [Sociolingustic Study on Japanese language in Hawaii]. In Gakujutsu Geppô [Monthly Report of Academic Research]. Tokyo: Japan Society for the Promotion of Science, vol. 26, pp. 29-35.

Higa, Masanori. 1982. Burajiru ni okeru Nihon-jin ijûsha no Gengotekiô [Language accommodation of Japanese Immigrants in Brazil]. In Raten Amerika Kenkyû [Laten American Studies]. Tsukuba Laten American Studies Project. Ibaraki: Tsukuba University, vol. 4, pp. 154-63.

Inoue, Fumio. 2004. Nihongo Wotchingu [Japanese Language Watching]. Tokyo: Iwanami.

Kuyama, Megumi. 2000. Lexical borrowing from Portuguese by Japanese immigrants in Brazil: An analysis of its form and function. The Japanese Journal of Language in Society 3: 4-16.

Minami, Fujio. 1974. Keigo Kenkyû no Kanten [The perspective of honorific Language]. In Keigo Kenkyû no Hôhô [The Methods of Honorific Language Study]. Tokyo: Meiji Shoin, pp. 7-34. 
Mita, Chiyoko. 2011. Decasségui phenomenon of twenty five years-Changes of society in Japan and Brazil. In Jinken to Buraku mondai [Human Rights and Community of Buraku Problem] No. 811. Kyoto: Burakumondai Kenkyûsho, pp. 16-28.

Mizuki, John. 1978. The Growth of Japanese Churched in Brazil. Pasadina: William Carey Library, p. 17.

Mufwene, Salikoko. 1996. The founder principle in Creole genesis. Diachronica 13: 83-134. [CrossRef]

Müller, Simone. 2005. Discourse Markers in Native and Non-Native English Discourse. Philadelphia: John Benjamins, p. 20.

Nagata, Takashi. 1990. Burajiru Nikkei shakai no Nihongo gengo seikatsu: Parana shû Asai o rei ni [The linguistic aspect of Japanese Brazilian society: The case of Assai in the state of Parana]. Bulletin of the School of Literature, Arts and Cultural Studies 2: 41-67.

Nakamizu, Ellen. 1996. Social networks and the use of Japanese in spoken discourse of Brazilian guest workers. Handai Nihongo Kenkyu [Osaka University Japanese Studies] 8: 57-71.

Nakamizu, Ellen. 1997. Stages of style shifting acquisition in Japanese: The case of Brazilian guest workers. Handai Nihongo Kenkyu [Osaka University Japanese Studies] 9: 77-94.

Nakamizu, Ellen. 1998. On the use of verbs in Japanese language by Brazilian guest workers: From natural acquisition to formal learning. Handai Nihongo Kenkyu [Osaka University Japanese Studies] 10: 83-110.

National Language Institute. 1983. Keigo to Keigo ishiki: Okazaki ni okeru 20 nen mae to no hikaku [Socio-Psychological Survey on Japanese Polite Expression: After 20 Years from the Preceding Survey in Okazaki City, Aichi Pref]. Report No. 77. Tokyo: Sanseidô.

Nihon imin 80nen-shi hensan iinkai [Committee for Compiling Eighty-Year History of Japanese Immigration to Brazil]. 1991. Burajiru Nihon imin 80nen shi [80 Years of History of Japanese Immigrants to Brazil]. São Paulo: Nihon imin 80nen-shi hensan iinkai, pp. 245-385.

Nishida, Naotoshi. 1995. Keigo [Polite Language]. Tokyo: Tokyodô-shuppan.

Nomoto, Kikuo. 1969. Burajiru dayori: Burajiru no Nihongo [Letter from Brazil: Japanese language in Brazil]. In Gengo Seikatsu [Language Life] 214. Tokyo: Chikuma Shobô, pp. 72-73.

Ono, Susumu. 1999. Nihongo Renshûchô [Japanese Exercise Book]. Tokyo: Iwanami Shoten, p. 153.

Reichl, Christopher A. 1995. Stages in the historical process of ethnicity: The Japanese in Brazil. 1908-1988. Ethnohistory 42: 31-62. [CrossRef]

Sanada, Shinji. 1993. Chiiki gengo no shakai gengogaku-teki kenkyû [Sociolinguestic Studies on Japanese regional language]. Osaka: Izumishoin.

Suzuki, Hideo. 1982. Burajiru ni okeru Nihongo no henyô [Japanese language change in Brazil]. In Nagoya Daigaku Kyôyôbu Kiyô [Bulletin of the Faculty of Liberal arts of Nagoya University] No. 26. Nagoya: Nagoya University, pp. 91-115.

The Consular and Emigration Affairs Department, The Ministry of Foreign Affairs. 1971. Waga kokumin no kaigai hatten-Ijû hyakunen no ayumi-[Overseas Expansion of Japanese People-History of Immigration during One Hundred Year]; Tokyo: The Ministry of Foreign Affairs, pp. 52-53, 140-41.

Tsujimura, Toshiki. 1992. Keigo-ronkô [Discussion on Polite Language]. Tokyo: Meijishoin, p. 446.

Uchiyama, Masao. 2001. Sôbô no Kyûjû ni nen-Burajiru imin no kiroku [Ninty Two Years of Wasteland-Record of Japanese Immgrants to Brazil]. Tokyo: Tokyo Shimbun shuppankyoku, p. 16.

Varghese, Manka, and Kristine BillMyers. 1996. Investigation the Structure of Discourse Completion Tests. Working Papers in Educational Linguistics 12: 39-58.

Yamashita, Akemi. 1995. Nikkei Imin no Teijû to Gengo Mondai [Nikkei settlement and problems of language]. In Sociology of movement and settlement. Cross-National Comparative Research in Sociology. Edited by Shôgo Koyano and Shigeru Yamate. Tokyo: Gakuyô shobô, pp. 171-81.

Yamashita, Akemi. 1997. Imin to Gengohenyô [Immigration and Language Change]. In Kokusai Idô Ron [Theory of International Migration]. Edited by Mitsuo Ogura. Tokyo: Mitsumine-shobô, pp. 209-240.

Yamashita, Akemi. 1999a. Nihonzaijû Nikkei Burajirujin no Nihongo [A study of the Japanese language among Japanese Brazilian people]. Meikai University the Journal of Arts and Sciences 11: 39-50.

Yamashita, Akemi. 1999b. Nikkeijin no Taigûhyôgen no Taikei to Sore o Sasaeru Yôin [The structure of the polite expression among people of Japanese parentage]. In Gengo Chiiki Bunka Kenkyû 5 [Language Area and Cultural Studies]. Tokyo: Tokyo University of Foreign Studies, vol. 5, pp. 1-20. 
Yamashita, Akemi. 2003. Influence of Western Japanese Dialect on Japanese language spoken by Nikkei Brazilians. Paper presented at the IVth International Congress of Dialectologists and Geolinguists, Riga, Latvia, June.

Yamashita, Akemi. 2007. Kaigai no Nihongo no Atarashii Gengo Chitsujo [A New Order of Japanese Abroad]. Tokyo: Sangensha. 